\title{
Speedy Grammar: Aplikasi Game untuk Meningkatkan Kemampuan Tata Bahasa Inggris Siswa
}

\section{Speedy Grammar: A Game Application to Improve Student's English Grammar}

\author{
Awaliyah Ainun Niswah \\ Universitas Airlangga \\ Kampus B Universitas Airlangga, Jl. Dharmawangsa Dalam, Surabaya, Jawa Timur, Indonesia \\ Email: awaliyah.ainun.niswah-2020@fib.unair.ac.id; Orcid: https://orcid.org/0000-0001-7196-4091
}

\begin{abstract}
ARTICLE HISTORY
Received 9 October 2021

Accepted 26 December 2021

Published 1 February 2022

\section{KEYWORDS}

game apps, speedy grammar, improved, English grammar.

\section{KATA KUNCI}

aplikasi game, speedy grammar, peningkatan, tata bahasa Inggris.

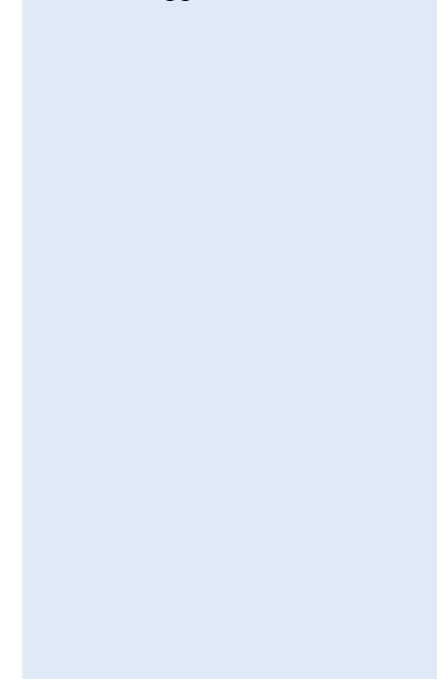

ABSTRACT

This study aims to see the improvement of English grammar by students who practice using the Speedy Grammar game application with students who do not use it, then compare them. This research design is quantitative with an experimental method between two classes (experimental and control class). The subjects of this study were 20 students. As a result, the ability of students who took advantage of the game application increased significantly than students who did not use the application. It can be proven by the value of the pretest and posttest results. During the pretest, the experimental class had a score of 64.70, and the control class had a score of 65.50. Meanwhile, after practicing six times with a duration of 30-50 minutes, the posttest score for the experimental class was 89.60, and the control class was 79.40. Another accurate proof as the answer to the research results of a 2-way (t-tailed) significance value between the two classes shows the number 0.000 on the posttest, so there is a very significant difference. The conclusion again states that the Speedy Grammar game application can be used to solve problems when learning English grammar.

\section{ABSTRAK}

Penelitian ini dilakukan bertujuan untuk melihat peningkatan kemampuan tata bahasa Inggris yang dimiliki para siswa yang berlatih menggunakan aplikasi game Speedy Grammar dengan siswa yang tidak menggunakan aplikasi tersebut, serta melihat perbandingannya. Ancangan penelitian ini adalah kuantitatif dengan metode eksperimental antara dua kelas, yakni kelas eksperimen dan kelas kontrol. Subjek penelitian ini adalah 20 siswa. Hasil penelitian terungkap bahwa kemampuan gramatika Inggris yang dimiliki siswa yang memanfaatkan aplikasi game tersebut meningkat secara signifikan dibandingkan dengan siswa yang tidak menggunakan aplikasi tersebut. Hal ini bisa dibuktikan dengan nilai angka hasil dari pretes dan postes. Saat pretes, kelas eksperimen memiliki nilai 64,70 dan kelas kontrol memiliki nilai 65,50. Adapun setelah berlatih selama 6 kali berdurasi 30-50 menit, nilai postes mengatakan kelas eksperimen 89,60 dan kelas kontrol 79,40. Pembuktian lebih akurat untuk menjawab tujuan penelitian ini hasil nilai signifikansi 2 arah ( $t$-tailed) antara dua kelas tersebut memperlihatkan angka 0,000 pada hasil postes, ini menandakan ada perbedaan yang sangat signifikan. Simpulan lain lagi mengatakan bahwa aplikasi game Speedy Grammar dapat dijadikan sebagai solusi atas permasalahan, jika ada pelajar bahasa yang mengalami kesulitan saat belajar tata bahasa Inggris.
\end{abstract}

\section{To cite this article:}

Niswah, A. A. (2022). Speedy Grammar: Aplikasi Game untuk Meningkatkan Kemampuan Tata Bahasa Inggris Siswa. Diglosia: Jurnal Kajian Bahasa, Sastra, dan Pengajarannya, 5(1), 163-174. https://doi.org/10.30872/diglosia.v5i1.309 


\section{A. Pendahuluan}

Tata bahasa termasuk komponen penting untuk mengukur kemampuan berbahasa para siswa atas bahasa yang telah dipelajarinya. Tidak sempurna, jika para pelajar dinilai mahir berbahasa namun hanya menguasai beragam kosakata saja (Santosa, 2017; Agustin, 2015; Mardiana et al., 2018). Artinya, selain menguasai beragam kosakata, para pelajar itu perlu menguasai struktur tata bahasa untuk menyusun beragam kosakata itu. Belajar tata bahasa merupakan suatu hal yang tidak mudah, terutama jika tata bahasa yang dipelajari itu bukan bahasa pertama, melainkan bahasa kedua. Hal itu karena masingmasing bahasa memiliki kaidah atau tata bahasa tersendiri. Salah satu contoh misalnya, bahasa Indonesia memiliki tata bahasa tersendiri, begitu pun bahasa Inggris memiliki struktur bahasa tersendiri. Untuk itu, tata bahasa dari kedua bahasa tersebut tidak dapat disamakan. Hal itulah menjadi keistimewaan bahasa.

Upaya untuk meningkatkan kemampuan tata bahasa, salah satunya tentu dengan adanya latihan. Latihan itu tidak cukup jika dilakukan hanya sesekali, melainkan butuh waktu berkali kali untuk berlatih. Untuk itu, sangat ditekankan bahwa latihan merupakan bagian primer dalam proses belajar. Mengingat saat ini sedang maraknya perkembangan teknologi, teori pembelajaran abad 21 sedang naik daun. Teori belajar abad 21 menuntut para pendidik untuk melangsungkan pembelajaran efektif yang menyenangkan (Syahputra, 2018; Islami \& Amalia, 2020). Itu karena model suasana pendidikan abad 21 didesain dengan sedemikian rupa sehingga menghasilkan suasana yang menyenangkan dan tidak lagi menyeramkan bagi peserta didik. Salah satu prinsip pembelajaran abad 21 adalah peserta didik tidak lagi dituntut untuk mendengarkan dan menghafal materi pelajaran, namun berupaya membangun pengetahuan dan keterampilannya dengan suasana yang mengasyikkan. Perkembangan teori pembelajaran 21 ini ditandai dengan pemanfaatan teknologi informasi dan komunikasi dalam proses belajar mengajar (Effendi \& Wahidy, 2019; Mardhiyah et al., 2021). Media maupun metode pembelajaran yang dapat menarik hati para peserta didik, tidak luput dari peran perkembangan teknologi. Dengan diterapkannya teori pembelajaran 21 serta kemajuan teknologi ini, menghasilkan beragam media pembelajaran demi meningkatkan minat belajar peserta didik.

Dalam pembelajaran bahasa tentunya ada beragam metode dan media berbasis teknologi yang bisa diterapkan. Penelitian mengenai penggunaan media maupun metode yang berbasis teknologi untuk peningkatan berbahasa, khususnya pada peningkatan tata bahasa sudah banyak dilakukan. Itu menandakan bahwa para pelajar bahasa sering menemui kesulitan saat belajar tata bahasa, namun disisi lain juga terungkap bahwa ada banyak media teknologi yang memfasilitasi belajar tata bahasa dan bisa sebagai solusi atas kesulitan tersebut. Seperti riset yang dilakukan oleh Rifai et al. (2020), di mana dalam risetnya, mereka membandingkan kemampuan tata bahasa Jepang para siswa. Pengujian itu dilakukan antara siswa yang berlatih dengan menggunakan media berbentuk aplikasi yang berbasis chatbot, khusus nama aplikasinya Gengobot dengan siswa yang berlatih tidak menggunakan media aplikasi tersebut. 
Hasilnya, dibuktikan bahwa kemampuan gramatika siswa yang menggunakan aplikasi Gengobot lebih meningkat secara signifikan dibandingkan dengan siswa yang tidak menggunakan aplikasi tersebut. Berdasarkan riset yang dilakukan oleh Rifai dapat dimaknai bahwa penggunaan media yang tepat untuk belajar tata bahasa akan berpengaruh dalam meningkatkan kemampuan terkait bidang yang telah dipelajari itu.

Selain itu, Liana et al. (2018) melakukan sebuah eksperimen terhadap para siswa untuk meningkatkan kemampuan berbahasa Inggris dengan menggunakan aplikasi Hello English. Meskipun yang difokuskan adalah kemampuan listening, namun sangat ditekankan pada latihan tata bahasanya terlebih dahulu. Itu karena jika para siswa menguasai tata bahasa yang baik akan sangat berpengaruh terhadap peningkatan kemampuan listening. Hasilnya, terungkap bahwa penggunaan aplikasi Hello English sangat berpengaruh untuk meningkatkan kemampuan berbahasa Inggris, tentunya pada kemampuan tata bahasa yang dapat mempengaruhi peningkatan penguasaan listening. Tidak kalah menarik dengan riset yang pernah dilakukan oleh Hapsari \& Wulandari (2020) di era pandemi ini, sepasang penulis ini juga telah memanfaatkan teknologi untuk mempermudah proses pembelajaran bahasa dengan jarak jauh yang menerapkan sistem belajar mandiri. Sepasang penulis, Hapsari \& Wulandari (2020) sengaja melakukan penelitian ini dengan tujuan ingin mendeskripsikan validitas buku ajar milenial berbasis teknologi Augmented Reality dalam pembelajaran bahasa, khususnya bahasa Indonesia pada tingkat Sekolah Menengah Pertama (SMP). Jadi, jenis penelitian yang dilakukan sepasang peneliti ini adalah Research and Develeopment (R\&D). Hasil dari uji kelayakan memperlihatkan bahwa buku ajar milenial berbasis teknologi AR sangat layak digunakan dalam pembelajaran bahasa serta sangat memadai jika diaplikasikan dalam pembelajaran teks prosedur siswa.

Berdasarkan tiga riset yang sudah pernah dilakukan di atas, dapat disimpulkan bahwa media pembelajaran di era teknologi yang serba maju seperti saat ini, sudah semakin canggih dan sangat beragam. Itu artinya, media belajar berbasis teknologi harus dimanfaatkan sebaik mungkin untuk meningkatkan semua bidang pelajaran, salah satunya bidang berbahasa.

Dalam upaya menghadirkan fun learning saat proses belajar berlangsung salah satunya adalah difasilitasi dengan media sebuah game. Pembelajaran berbasis game, mampu menstimulasi peserta didik untuk menikmati proses pembelajaran. Peserta didik dibuat aktif dan senang dalam belajar (Pakpahan et al., 2020). Hal itu sangat sesuai, jika media berbasis game ini diterapkan dalam proses latihan tata bahasa yang dilakukan berkali-kali demi meningkatkan kemampuan. Untuk itu, dalam riset ini melakukan sebuah eksperimen terhadap para siswa dengan menjadikan aplikasi berbasis game sebagai media pembelajaran untuk meningkatkan kemampuan tata bahasa Inggris. Aplikasi game yang digunakan adalah Speedy Gammar.

Penelitian mengenai media pembelajaran bahasa berbasis game sudah kerap dilakukan, apalagi di era teknologi yang semakin maju seperti saat ini. Banyak peneliti yang memanfaatkan kemajuan teknologi untuk membuat game yang dijadikan sebagai media pembelajaran, khususnya pada bidang bahasa. 
Salah satunya seperti oleh Rahayu (2018). Dalam risetnya, Rahayu sengaja memanfaatkan teknologi untuk membuat game edukasi sebagai media pembelajaran yang interaktif untuk pelajar usia anak dini. Game itu dirancang dengan metode GDD (Game Design Documen) yang terdiri atas overview, genre target audience, look and feel, feature set, mission/challenge/tantangan, reward dan play flow. Penggunaan game sebagai media pembelajaran ini tentunya dengan dampingan para guru. Hasilnya terungkap bahwa game yang telah dibuat Rahayu \& Fujiati (2018) tersebut, mampu sebagai pendukung para peserta didik dalam memperkaya beragam kosakata bahasa Inggris. Peristiwa seperti ini pernah juga diungkap oleh Klimova \& Kacet (2017), di mana mereka berdua melakukan peninjauan beberapa literatur terkait dengan khasiat game komputer pada pembelajaran bahasa. Pencarian literatur itu dilakukan dari database Web of Science, Scopus, ScienceDirect, dan Springer. Dalam riset yang dilakukan oleh mereka berdua ini, bertujuan untuk mengeksplorasi kemanjuran game komputer jika diterapkan sebagai media pembelajaran, khususnya pada belajar bahasa. Selain itu, Klimova \& Jaroslav juga menelaah beragam manfaat yang diperoleh peserta didik dari bermain game komputer itu. Dari beberapa literatur yang ditemukan, terungkap bahwa game komputer jika diterapkan sebagai media pembelajaran bahasa sangat berpengaruh sebagai pendukung keefektifan penguasaan kosakata bahasa asing. Selain itu, dipaparkan juga bahwa kemampuan berbicara dengan berbahasa asing yang dipelajari itu semakin meningkat, artinya peserta didik sangat lancar berkomunikasi dengan menggunakan bahasa target tersebut.

Berdasarkan beberapa riset yang ditemukan di atas, ini menandakan bahwa belajar bahasa dengan media pembelajaran berbasis game itu asyik dan menyenangkan. Para pelajar diajak menikmati dengan sukaria saat mempelajari bahasa tersebut. Ketika awalnya jenuh dan bosan saat belajar bahasa, kini dengan adanya game sebagai media pembelajaran, kejenuhan dan kebosanan itu menjadi sirna. Hal itu karena belajar seolah-olah hanya bermain game yang sangat asyik. Keasyikan itulah yang dapat mempengaruhi peningkatan kemampuan bahasa asing sebagai bahasa target pembelajaran. Beberapa riset yang telah disebutkan di atas, fokus kemampuan yang ditingkatkan adalah untuk memperkaya kosakata agar komunikasi itu menjadi semakin lancar. Berbeda dari itu, pada kesempatan ini, penelitian yang dilakukan akan berfokus pada tata bahasa, yakni peningkatan tata bahasa asing - bahasa Inggris. Peningkatan tata bahasa Inggris ini dengan menggunakan aplikasi game juga sebagai media pembelajaran. Nama aplikasi game itu adalah Speedy Grammar. Jadi, riset yang dilakukan ini bertujuan untuk membuktikan keefektifan penggunaan aplikasi game Speedy Grammar jika diterapkan sebagai media pembelajaran khususnya pada tata bahasa Inggris. Agar hasil penelitian nanti bisa terbukti dengan jelas, maka riset ini melakukan perbandingan kemampuan tata bahasa Inggris oleh para siswa yang berlatih dengan menggunakan aplikasi game Speedy Grammar dengan para siswa yang tidak menggunakan aplikasi tersebut. 


\section{B. Metode}

Metode dalam penelitian ini adalah eksperimental kuantitatif, dengan desain penelitian pretes-postes control-group design yang terdapat dua kelas penelitian, yaitu kelas eksperimen dan kelas kontrol. Kedua kelas ini akan dilakukan pretes dan postes. Mengingat tujuan riset ini adalah untuk membandingkan kedua kelas tersebut, untuk itu hanya satu kelas yang akan dilakukan treatment penelitian, yaitu hanya pada kelas eksperimen saja (Creswell, 2014).

Para siswa dari kedua kelas ini: kelas eksperimen dan kelas kontrol, semuanya memiliki kemampuan bahasa inggris pada tingkat dasar. Kelas eksperimen yang dimaksud dalam penelitian ini adalah kelas yang menggunakan aplikasi game Speedy Grammar sebagai media latihan tata bahasa Inggris. Sedangkan kelas kontrol adalah kelas yang menggunakan soal-soal latihan kertas yang diberikan oleh peneliti. Sebelum dilaksanakan treatment penelitian untuk kelas eksperimen, dilakukan pretes terlebih dahulu untuk mengetahui kemampuan seluruh para siswa dari kedua kelas tersebut. Kemudian di akhir penelitian, dilakukan postes dari kedua kelas tersebut. Berdasarkan hasil dari postes tersebut dapat dilihat perbedaan antara kelas yang mengikuti treatment, yakni pada kelas eksperimen dan kelas yang kontrol yang tidak mengikuti treatment. Setelah diketahui hasil perbedaan dari kedua kelas tersebut, kemudian dibandingkan antara keduanya.

Penelitian ini mempunyai dua hipotesis, yaitu; pertama, penggunaan aplikasi game Speedy Grammar sebagai media pembelajaran tata bahasa Inggris yang dapat digunakan oleh pelajar bahasa Inggris tingkat dasar; kedua, terlihat perbedaan yang jelas antara pelajar yang menggunakan aplikasi game Speedy Grammar sebagai media latihan dengan pelajar yang tidak memanfaatkan aplikasi tersebut, yakni pelajar yang memanfaatkan soal latihan konvensional dengan kertas.

Subjek penelitian ini adalah para siswa kelas 4 Ml Ihyaul Ulum, Bluri, Lamongan dengan sampel 10 siswa untuk kelas eksperimen dan 10 siswa untuk kelas kontrol. Instrumen penelitian ini ada tiga; pertama, aplikasi game Speedy Grammar yang akan digunakan sebagai media untuk kelas eksperimen; kedua, instrumen tes untuk praktik pretes dan postes untuk kedua kelas; ketiga, instrumen angket untuk kelas eksperimen.

Upaya mendapatkan hasil penelitian lebih akurat serta optimal, teknik analisis data yang akan digunakan dibagi menjadi dua bagian. Analisis pertama dari data hasil pretes dan postes, sedangkan analisis kedua dari data hasil angket penggunaan aplikasi game tersebut. Dalam proses analisis data pertama, yakni hasil dari pretes dan postes, akan digunakan uji-t, yakni independent sample t-test dengan memanfaatkan SPSS 24. Uji $t$-test independen merupakan salah satu uji parametrik untuk melakukan komparasi independen. Hal itu sesuai dengan tujuan penelitian ini yang akan membandingkan hasil nilai dari postes antara kelas eksperimen dan kontrol. Untuk mengukur perbedaan rata-rata pada dua kelas tersebut, digunakan pedoman: (1) nilai signifikansi (2-tailed) $>0.05$ memperlihatkan tidak ada perbedaan rata-rata; dan (2) nilai signifikansi (2-tailed) $<0,05$ memperlihatkan adanya perbedaan rata-rata. 
Tabel 1. Tingkat Persetujuan dan Bobot Nilai

\begin{tabular}{lc}
\hline Tingkat Persetujuan & Bobot Nilai \\
\hline Sangat setuju (SS) & 5 \\
Setuju (S) & 4 \\
Ragu-ragu (RG & 3 \\
Tidak setuju (TS) & 2 \\
Sangat tidak setuju (STS) & 1 \\
\hline
\end{tabular}

Tabel 2. Pedoman Penilaian Skala Likert (Sudjiono, 2010)

\begin{tabular}{cl}
\hline Jawaban $(\%)$ & Keterangan \\
\hline 0 & Tidak seorang pun \\
$1-5$ & Hampir tidak ada \\
$6-25$ & Sebagian kecil \\
$26-49$ & Hampir setengahnya \\
50 & Setengahnya \\
$51-75$ & Lebih dari setengahnya \\
$76-95$ & Sebagian besar \\
$96-99$ & Hampir seluruhnya \\
100 & Seluruhnya \\
\hline
\end{tabular}

Tabel 3. Kategori Persentase Frekuensi

\begin{tabular}{ccl}
\hline No. & Persentase Frekuensi (\%) & Kategori \\
\hline 1. & $81-100$ & Sangat baik \\
2. & $61-80$ & Baik \\
3. & $41-60$ & Cukup \\
4. & $21-40$ & Kurang \\
5. & $0-20$ & Sangat Kurang \\
\hline
\end{tabular}

Aplikasi SPSS 24 dimanfaatkan sebagai penolong pada perhitungan terkait analisis data. Akan halnya dengan proses analisis kedua terkait hasil analisis angket, penelitian ini memfungsikan angket skala likert, di mana bentuk penilaiannya terdapat 5 tingkat persetujuan. Dari 5 tingkat persetujuan tersebut, memiliki bobot nilai atau skor likert masing-masing. Untuk lebih detailnya dapat dilihat pada Tabel 1. Kemudian, data yang berupa 5 persetujuan itu akan diolah dengan memanfaatkan Microsoft Excel untuk mendapatkan persentase frekuensi dari setiap jawaban, lalu kemudian data tersebut diinterpretasikan dengan pedoman pada Tabel 2. Selanjutnya, jawaban berupa persentase frekuensi itu dikategorikan menjadi lima kategori sebagaimana Tabel 3.

\section{Pembahasan}

\section{Aplikasi Game Speedy Grammar}

Instrumen pertama penelitian ini adalah Aplikasi game Speedy Grammar. Aplikasi game Speedy Grammar ini dirancang oleh Wobble Monkey Studios. Game tersebut merupakan game yang asyik dan seru untuk belajar tata bahasa Inggris. Itu karena game Speedy Grammar ini memiliki metode belajar yang unik dan menarik. Game ini memfasilitasi lebih dari 200 simpe lesson dan latihan tata bahasa yang berbasis permainan. Artinya, selain dapat meningkatkan penguasaan tata bahasa, bermain dengan game ini juga dapat memperluas 
kosakata dan meningkatkan keterampilan listening dan speaking. Untuk itu, game ini sangat cocok untuk pelajar bahasa Inggris tingkat pemula ataupun dasar sampai pelajar tingkat menengah (A1, A2, dan B1).

Pada tingkat pemula ataupun dasar, terdapat fitur sebagai berikut: (1) present simple tense-the verb "to be" and other verbs; (2) past simple tenseregular verbs and irregular verb conjugation; (3) articles, pronouns and possessives; (4) singular and plural forms; (5) positive and negative phrases; (6) question forms and short answers; (7) demonstrative pronouns; (8) determiners and conjunctions; (9) present continuous/progressive tense; (10) basic adjectives and adverbs; (11) comparatives and superlatives; (12) future; (13) imperative; (14) present perfect tense - regular verbs and irregular verb conjugation; (15) basic time words and phrases and the use of different tenses; dan masih banyak lagi. Adapun fitur pada level menengah sebagai berikut: (1) prepositions, (2) past continuous tense, (3) action verbs vs state verbs, (4) conditional tenses, (5) the passive voice, (6) relative clauses, (7) prefixes and suffixes dan masih banyak lagi.

\section{Penggunaan Speedy Grammar untuk Peningkatan Kemampuan Tata Bahasa}

Pelaksanaan pretes oleh dua kelas dilakukan di awal penelitian demi mengetahui kemampuan masing-masing pelajar dari setiap kelas tersebut. Selanjutnya, dilaksanakan pertemuan selama 6 kali berdurasi 30-50 menit pada kelas eksperimen dan kontrol. Dalam pertemuan itu, ada sebuah permintaan yang ditujukan kepada kelas eksperimen dan kelas kontrol. Permintaan yang ditujukan kepada kelas eksperimen berupa suruhan untuk bermain game speedy Grammar. Meskipun itu terkesan seolah-olah hanya bermain game, namun di dalamnya terdapat banyak latihan dengan menjawab beragam pertanyaan yang disediakan oleh aplikasi game tersebut. Untuk itu, para siswa yang berada di dalam kelas eksperimen, saat bermain game pada aplikasi speedy Grammar secara otomatis pasti menjawab atau mengerjakan soal yang ada di dalam aplikasi tersebut. Sementara, permintaan yang ditujukan kepada kelas kontrol berupa suruhan untuk menggunakan media konvensional dalam mengerjakan soal latihan di atas kertas dengan topik yang sama dengan kelas eksperimen itu, yakni soal yang ada di aplikasi game speedy Grammar dan soal yang di kertas itu bertopik sama. Pada akhir penelitian ini, dilaksanakan postes demi mengetahui kemampuan para siswa setelah melakukan pelatihan dari masingmasing kelas.

Penelitian ini memanfaatkan SPSS 24 untuk menganalisis hasil data dari pretes maupun postes dari dua kelas tersebut. Berdasarkan aplikasi SPSS 24 itu, terungkap pada Tabel 4. Selanjutnya, untuk melihat nilai signifikansi 2 arah (t-tailed) $0,000<0,05$, riset ini menggunakan analisis data independent sample $t$-test sehingga terlihat perbedaan skor poin yang signifikan antara kelas eksperimen dan kelas kontrol. Untuk lebih jelasnya dapat dilihat pada Tabel 5.

Jika kita amati lebih dalam pada tabel 4, itu terlihat kelas kontrol memiliki nilai rata-rata pretes lebih tinggi dari pada kelas eksperimen. Namun, pada nilai rata- 
rata postes, hasil yang keluar itu berbeda, kelas eksperimen justru mengalami peningkatan yang begitu pesat. Kelas eksperimen mampu bersaing mengalahkan skor nilai kelas kontrol.

Adapun pada tabel 5, jika dicermati lagi, nilai pretes dari kedua tersebut terbilang 0,864, di mana lebih besar dari 0,05, itu menandakan bahwa tidak ada perbedaan nilai yang signifikan dari kedua kelas tersebut. Sedangkan jika dilihat pada nilai postes yaitu 0,000 , di mana lebih kecil dari 0,05 yang menandakan bahwa terdapat perbedaan nilai rata-rata yang signifikan dari kedua kelas tersebut. Untuk itu, berdasarkan hasil uraian pada Tabel 4 dan 5, sangat terbukti dengan jelas dan terungkap bahwa kelas eksperimen jauh lebih unggul meningkat dari pada kelas kontrol. Hal itu bisa dibuktikan dari fakta yang ada. Untuk itu, bisa dikatakan bahwa latihan tata bahasa Inggris dengan aplikasi game Speedy Grammar jauh lebih efektif dari pada latihan di atas kertas dengan menggunakan media konvensional.

Berdasarkan peristiwa di atas, hipotesis peneliti dari perbedaan kemampuan yang terlihat dari hasil postes-kelas eksperimen jauh lebih unggul-didasari oleh teori pembelajaran abad 21 dengan fasilitas media aplikasi game Speedy Grammar. Dalam teori itu, adanya penerapan pembelajaran yang tidak lepas dari kehidupan sehari-hari. Maksudnya adalah anak seusia SD, dunia mereka masih sering bergelut di area permainan. Anak sepantaran mereka itu menganggap sebuah permainan adalah sebuah kebutuhan. Dengan adanya teori pembelajaran abad 21, peserta didik tidak lagi dituntut untuk mendengarkan dan menghafal materi pelajaran yang diberikan guru, namun bisa melakukan proses pembelajaran dengan suasana bermain yang menyenangkan. Menerapkan teori pembelajaran abad 21 dengan memanfaatkan teknologi informasi dan komunikasi seperti aplikasi game Speedy Grammar ini, para peserta didik merasakan sebuah kenyamanan dan menyenangkan dalam proses belajar. Para siswa dibuat berlomba-lomba satu sama lain untuk meningkatkan level permainan tersebut. Motivasi yang dimiliki para siswa meningkat begitu pun semangat yang dimiliki juga membara tanpa merasa ada tekanan karena diekspresikan secara enjoy. Tidak ada kebosanan dalam latihan karena pertanyaan pada aplikasi tersebut beragam, begitu juga aplikasi game tersebut memiliki fitur pemberian reward dan punishment yang secara langsung dapat menjadi sebuah evaluasi yang bisa sebagai pengingat kuat atas materi yang sedang dipelajari. Selain itu siswa juga dapat setiap saat melatih kemampuan tata bahasa Inggrisnya dengan memainkan aplikasi game Speedy Grammar ini.

Tabel 4. Hasil Nilai Pretes dan Postes

\begin{tabular}{lccc}
\hline Jenis Kelas & Jumlah Siswa & Nilai Rata-Rata Pretes & Nilai Rata-Rata Postes \\
\hline Eksperimen & 10 & 64,70 & 89,60 \\
Kontrol & 10 & 65,50 & 79,40 \\
\hline
\end{tabular}

\section{Tabel 5. Nilai Signifikansi 2 Arah (t-tailed)}

\begin{tabular}{lc}
\hline Jenis test & Sig, (2-tailed) \\
\hline Pretes & 0,864 \\
Postes & 0,000 \\
\hline
\end{tabular}


Tabel 6. Hasil Angket Penggunaan Aplikasi Game Speedy Grammar

\begin{tabular}{|c|c|c|c|c|c|c|c|}
\hline No. & Pertanyaan & SS & $\mathrm{S}$ & RG & TS & STS & $\begin{array}{c}\text { Index } \\
(\%)\end{array}$ \\
\hline \multicolumn{8}{|c|}{ Bagian 1. Terkait aplikasi Speedy Grammar } \\
\hline 1. & Mudah dan praktis digunakan & 15 & 3 & 2 & 0 & 0 & 93 \\
\hline 2. & Menarik dan inovatif & 16 & 4 & 0 & 0 & 0 & 96 \\
\hline 3. & $\begin{array}{l}\text { Memiliki fitur bermanfaat dan mudah } \\
\text { dipahami }\end{array}$ & 14 & 4 & 2 & 0 & 0 & 92 \\
\hline Rata- & ata & 15 & 4 & 1 & $\mathbf{0}$ & $\mathbf{0}$ & 94 \\
\hline \multicolumn{8}{|c|}{ Bagian 2. Terkait konten aplikasi Speedy Grammar } \\
\hline 1. & $\begin{array}{l}\text { Tata bahasa sesuai dengan pelajar } \\
\text { level dasar }\end{array}$ & 17 & 3 & 0 & 0 & 0 & 97 \\
\hline 2. & $\begin{array}{l}\text { Soal latihan sesuai dengan pelajar } \\
\text { level dasar }\end{array}$ & 12 & 4 & 3 & 1 & 0 & 87 \\
\hline 3. & $\begin{array}{l}\text { Materi lengkap sesuai dengan pelajar } \\
\text { level dasar }\end{array}$ & 9 & 7 & 2 & 2 & 0 & 83 \\
\hline Rata- & & 13 & 5 & 2 & 1 & 0 & 89 \\
\hline \multicolumn{8}{|c|}{ Bagian 3. Terkait pengaruh aplikasi Speedy Grammar } \\
\hline 1. & $\begin{array}{l}\text { Speedy Grammar layak sebagai } \\
\text { media pembelajaran tata bahasa } \\
\text { Inggris }\end{array}$ & 19 & 1 & 0 & 0 & 0 & 99 \\
\hline 2. & $\begin{array}{l}\text { Speedy Grammar kompatibel untuk } \\
\text { pembelajaran mandiri }\end{array}$ & 20 & 0 & 0 & 0 & 0 & 100 \\
\hline 3. & $\begin{array}{l}\text { Speedy Grammar dapat } \\
\text { meningkatkan motivasi belajar tata } \\
\text { bahasa Inggris }\end{array}$ & 20 & 0 & 0 & 0 & 0 & 100 \\
\hline 4. & $\begin{array}{l}\text { Kemampuan tata bahasa Inggri } \\
\text { meningkat setelah menggunakan } \\
\text { Speedy Grammar }\end{array}$ & 20 & 0 & 0 & 0 & 0 & 100 \\
\hline 5. & $\begin{array}{l}\text { Speedy Grammar akan saya } \\
\text { gunakan lagi untuk berlatih tata } \\
\text { bahasa Inggris }\end{array}$ & 18 & 2 & 0 & 0 & 0 & 98 \\
\hline \multicolumn{2}{|c|}{ Rata-rata } & 19 & 1 & $\mathbf{0}$ & $\mathbf{0}$ & $\mathbf{0}$ & 99 \\
\hline
\end{tabular}

Tabel 6 adalah hasil angket penggunaan aplikasi game Speedy Grammar dari kelas eksperimen. Ada 11 pertanyaan pada Tabel 6 mengenai angket penggunaan aplikasi game Speedy Grammar yang ditujukaan kepada kelas eksperimen karena sebagai kelas pengguna. Pertanyaan dengan jumlah 11 itu dibagi menjadi 3 bagian, di antaranya terkait tentang aplikasi Speedy Grammar, konten aplikasi Speedy Grammar dan pengaruh dari aplikasi Speedy Grammar. Bagian pertama mengenai aplikasi dengan 3 pertanyaan, di mana 3 pertanyaan itu ditanggapi dengan persentase $94 \%$ dan masuk dalam kategori "sangat baik". Selanjutnya, bagian kedua terkait konten aplikasi dengan 3 pertanyaan yang ditanggapi dengan persentase $89 \%$ dan masuk dalam kategori "sangat baik". Bagian terakhir adalah terkait dengan pengaruh dari aplikasi tersebut dengan 5 pertanyaan dan memiliki persentase $99 \%$ dan masuk dalam kategori "sangat baik".

Berdasarkan hasil penelitian, dapat dipahami bahwa Speedy Grammar dapat dijadikan sebagai solusi atas permasalahan jika ada pelajar bahasa yang mengalami kesulitan saat belajar tata bahasa, khususnya bahasa Inggris. Hal itu dapat dibuktikan dengan 11 pertanyaan pada Tabel 6. Yang lebih ditekankan 
bahwa dengan Speedy Grammar, para siswa dapat belajar mandiri setiap saat, namun terkesan bermain game yang penuh keasyikan. Dengan adanya suasana yang asyik itu, para pelajar merasa lebih santai saat belajar sehingga akan lebih mudah dalam memahami materi tata bahasa Inggris itu. Untuk itu, dapat disimpulkan bahwa media pembelajaran berbasis game seperti Speedy Grammar ini sangat memukau hati para pelajar untuk digunakan sebagai media pembelajaran tata bahasa Inggris.

\section{Penutup}

Berdasarkan hasil uji serta analisis pada data pada penelitian ini, pertanyaan penelitian mengenai keefektifan penggunaan aplikasi game Speedy Grammar jika diterapkan sebagai media pembelajaran tata bahasa Inggris, telah terjawab disertai bukti yang akurat. Hasilnya terungkap bahwa ada peningkatan yang sangat terlihat jelas secara signifikan, kelas eksperimen saat melakukan pretes memiliki nilai 64,70 dan hasil nilai postesnya 89,60, sedangkan saat pretes kelas kontrol memiliki nilai 65,50 dan saat postes memiliki nilai 79,40 . Angka tersebutlah yang menjadi bukti atas keefektifannya penggunaan aplikasi game Speedy Grammar jika diterapkan sebagai media pembelajaran tata bahasa Inggris. Tidak hanya itu, ada pembuktian yang lebih akurat lagi untuk menjawab pertanyaan penelitian ini, yaitu dengan hasil nilai signifikansi 2 arah ( $t$-tailed) antara kelas eksperimen dan kelas kontrol dengan memperlihatkan angka 0,000 pada hasil postes dari kedua kelas tersebut, ini menandakan ada perbedaan yang sangat signifikan. Kelas eksperimen jauh mengalami peningkatan dari pada kelas kontrol.

Ada pelajaran lain yang dapat dipetik dari penelitian ini, di antaranya sebagai berikut. Latihan untuk meningkatkan sebuah kemampuan itu sangat penting dalam proses belajar. Semakin sering dilakukannya sebuah latihan maka kemampuan yang dimiliki akan semakin meningkat. Namun, dibalik itu ada yang lebih penting, yakni pada teori serta media pembelajaran. Artinya, teori dan media pembelajaran yang tepat akan sangat berpengaruh dalam peningkatan kemampuan. Kelas eksperimen menerapkan teori pembelajaran abad 21 yang difasilitasi dengan media pembelajaran berupa aplikasi game Speedy Grammar saat latihan, memiliki peningkatan kemampuan begitu pesat. Sedangkan kelas kontrol yang menerapkan media konvensional dengan menjawab pertanyaan pada sebuah kertas saat latihan, hanya mengalami sedikit peningkatan. Itu pertanda bahwa teori pembelajaran 21 serta fitur yang ada pada aplikasi game Speedy Grammar sangat mendorong untuk meningkatkan kemampuan tata bahasa Inggris pada pelajar tingkat dasar. Catatan lagi, terkait tanggapan terhadap aplikasi game Speedy Grammar sebagai media pembelajaran memiliki respons yang sangat baik. Artinya, dari hasil penelitian ini menyatakan Aplikasi game Speedy Grammar telah terindikasi efektif sebagai media pembelajaran tata bahasa Inggris untuk pelajar tingkat dasar. 


\section{Daftar Pustaka}

Agustin, Y. (2015). Penguasaan Tata Bahasa dan Berpikir Logik Serta Kemampuan Menulis Artikel IImiah. Jurnal IImiah Kependidikan, II(2), 123132. http://dx.doi.org/10.30998/fjik.v2i2.387

Creswell, J. W. (2014). Research Design Qualitative, Quantitative, and Mixed Methods Approaches. $4^{\text {th }}$ Edition. Singapore: Sage Publication.

Effendi, D., \& Wahidy, A. (2019). Pemanfaatan Teknologi dalam Proses Pembelajaran Menuju Pembelajaran Abad 21. Prosiding Seminar Nasional Pendidikan Program Pascasarjana Universitas PGRI Palembang, 125-129. https://jurnal.univpgripalembang.ac.id/index.php/Prosidingpps/article/view/2977/2799

Hapsari, T. P. R. N., \& Wulandari, A. (2020). Analisis Kelayakan Buku Ajar Milenial Berbasis Augmented Reality (AR) sebagai Media Pembelajaran Teks Prosedur di Magelang. Diglosia: Jurnal Kajian Bahasa, Sastra, dan Pengajarannya, 3(4), 351-364. https://doi.org/10.30872/diglosia.v3i4.125

Islami, A. D., \& Amalia, N. (2020). Pengembangan dan Penguatan Ketrampilan Belajar dan Inovasi Sebagai Bagian dari Ketrampilan Abad 21 pada Buku Siswa Kelas IV Edisi Revisi 2017. Jambura: Elementary Education Journal, 1(2), 111-122. https://ejournal-fipung.ac.id/ojs/index.php/jeej/article/view/151

Klimova, B., \& Kacet, J. (2017). Efficacy of Computer Games on Language Learning. Turkish Online Journal of Educational Technology, 16(4), 19-26. http://www.tojet.net/articles/v16i4/1643.pdf

Liana, R., Wahyudin, D., \& Hanoum, R. N. (2018). Pengaruh Penggunaan Aplikasi "Hello English" Berbasis Smartphone Android terhadap Peningkatan Hasil Belajar Siswa pada Mata Pelajaran Bahasa Inggris di SMP (Kuasi Eksperimen pada Mata Pelajaran Bahasa Inggris Siswa Kelas VII di SMP Negeri 1 Kadipaten). Edutechnologia, 2(2), 122-128. https://ejournal.upi.edu/index.php/edutechnologia/article/view/19667

Mardhiyah, R. H., Aldriani, S. N. F., Chittta, F., \& Zulfikar, M. R. (2021). Pentingnya Keterampilan Belajar di Abad 21 sebagai Tuntutan dalam Pengembangan Sumber Daya Manusia. Lectura: Jurnal Pendidikan, 12(1), 29-40. https://doi.org/10.31849/lectura.v12i1.5813

Mardiana, D., Kamaludin, A., \& Sutrisno, S. (2018). Pengaruh Kompetensi Grammar dan Penguasaan Kosakata terhadap Keterampilan Membuat Surat Bisnis Berbahasa Inggris pada Program Studi Administrasi Bisnis di Politeknik LP3I Jakarta Kampus Cileungsi. Jurnal Lentera Bisnis, 7(1), 1-10. https://doi.org/10.34127/jrlab.v7i1.210

Pakpahan, A. F., Putu, D., \& Arin, T. (2020). Pengembangan Media Pembelajaran. Medan: Yayasan Kita Menulis.

Rahayu, S. L., \& Fujiati. (2018). Penerapan Game Design Document dalam Perancangan Game Edukasi yang Interaktif untuk Menarik Minat Siswa dalam Belajar Bahasa Inggris. Jurnal Teknologi Informasi dan IImu Komputer, 5(3), 341-346. https://doi.org/10.25126/jtiik.201853694

Rifai, M. M., Haristiani, N., \& Risda, D. (2020). Gengobot: Chatbot Application to 
Enhance N4 Level Students' Japanese Grammar Ability. Japanedu: Jurnal Pendidikan dan Pengajaran Bahasa Jepang, 5(2), 134-140. https://doi.org/10.17509/japanedu.v5i2.30428

Santosa, P. P. P. (2017). Hubungan Antara Penguasaan Tata Bahasa dengan Keterampilan Menulis Narasi Bahasa Inggris Siswa Kelas XI SMK Negeri 2 Depok. Deiksis,

http://dx.doi.org/10.30998/deiksis.v9i02.1172 9(2), $\quad$ 182-193.

Sudjiono, A. (2010). Pengantar Statistik Pendidikan. Jakarta: Grafindo.

Syahputra, E. (2018). Pembelajaran Abad 21 dan Penerapannya di Indonesia. Seminar Nasional SINASTEKMAPAN (E-Journal), 1276-1283. https://www.researchgate.net/publication/331638425_PEMBELAJARAN_A BAD_21_DAN_PENERAPANNYA_DI_INDONESIA 